\title{
Hydrologic delineation of ground water potential zones using geospatial technique for Keleghai river basin, India
}

\author{
Nityananda $\mathrm{Sar}^{1} \cdot$ Ansar Khan $^{2} \cdot$ Soumendu Chatterjee $^{3} \cdot$ Arosikha Das $^{4}$
}

Received: 6 August 2015/ Accepted: 8 August 2015/Published online: 3 September 2015

(C) Springer International Publishing Switzerland 2015

\begin{abstract}
In the present paper, various groundwater potential zones for the assessment of groundwater availability in Keleghai river basin have been delineated using remote sensing (RS) and geographic information system (GIS) techniques. Survey of India (SOI) toposheets, field observations and satellite imageries are used to prepare various thematic layers viz. (a) drainage density, (b) geomorphology, (c) lineament density, (d) land use/land cover, (e) soil type, (f) water bodies density, (g) normalized difference vegetation index (NDVI), (h) slope and (i) mean annual rainfall were transformed to raster data using feature to raster converter tool in ArcGIS platform. The thematic maps have been ranked in a scale of 1-9 depending upon their suitability to hold groundwater. The rank of each map has been converted to a probability weight using Bayesian Decision Theory. Similarly, different categories of derived thematic maps were assigned scores in a numeric scale 1-9, depending upon their capability to store and transmit water. These scores were again converted capability values. This capability values $\left(c v_{i}\right)$ were then multiplied with the respective probability weight of each thematic map to arrive at the final weight map. Integration analysis was carried out using overlay-intersect method and a composite groundwater
\end{abstract}

Ansar Khan

khanansargeo@gmail.com

1 Department of Geography, Kharagpur College, Kharagpur, India

2 Department of Geography and Environment Management, Vidyasagar University, Midnapore, India

3 Department of Geography, Presidency University, Kolkata, India

4 Department of Applied Geography, Ravenshaw University, Cuttack, India potential map was generated. The composite potential index was obtained by multiplying weightages with rank numbers of each category and summing up the values of all categories. The resultant final map indicates the potentiality of groundwater occurrence in the study area. This map was then classified into five categorise based on the groundwater potential index value. The result depicts the groundwater potential zones in the study area and found to be helpful in better planning and management of groundwater resources.

Keywords Groundwater potential zones - Groundwater quality $\cdot$ Remote sensing (RS) - Geographic information system (GIS) · Keleghai river basin

\section{Introduction}

Groundwater is a vital natural resource for the reliable and economic provision of potable water supply in both urban and rural environment. Hence it plays a fundamental role in human well-beings, as well as that of some aquatic and terrestrial ecosystems. At present, groundwater contributes around $34 \%$ of the total annual water supply and is an important fresh water resource. So, an assessment for this resource is extremely significant for the sustainable management of groundwater systems. Geographic information system (GIS) and remote sensing (RS) tools are widely used for the management of various natural resources (Dar et al. 2010; Krishna Kumar et al. 2011; Magesh et al. 2011a, b). Delineating the potential groundwater zones using remote sensing and GIS is an effective tool. In recent years, extensive use of satellite data along with conventional maps and rectified ground truth data, has made it easier to establish the base line information for groundwater potential zones (Tiwari and Rai 1996; Das et al. 1997; Thomas 
et al. 1999; Harinarayana et al. 2000; Muralidhar et al. 2000; Chowdhury et al. 2010). Remote sensing not only provides a wide-range scale of the space-time distribution of observations, but also saves time and money (Murthy 2000; Leblanc et al. 2003; Tweed et al. 2007). In addition it is widely used to characterize the earth surface (such as lineaments, drainage patterns and lithology) as well as to examine the groundwater recharge zones (Sener et al. 2005). Applications of remote sensing and GIS for the exploration of groundwater potential zones are carried out by a number of researchers around the world, and it was found that the involved factors in determining the groundwater potential zones were different, and hence the results vary accordingly. Teeuw (1995) relied only on the lineaments for groundwater exploration and others merged different factors apart from lineaments like drainage density, geomorphology, geology, slope, land-use, rainfall intensity and soil texture (Sander et al. 1996; Das 2000; Sener et al. 2005; Ganapuram et al. 2008). The derived results are found to be satisfactory based on field survey and it varies from one region to another because of varied geo-environmental conditions. Development of groundwater in the study area is through construction of dug wells, dug-cum-bore wells and bore wells. However, recharging those groundwater sources is curtailed by frequent dry seasons and failure of monsoons. The minimum depth of the water table in the study area is $30 \mathrm{~m}$ in favourable localities adjoining rivers, canal system and abutting tanks, whereas the water table in remote areas is found very deeper up to 50-60 m resulting in acute water shortage. Exploitation of groundwater resources has increased in the past decades, leading to the over-consumption of groundwater, which eventually causes ecological problems such as decreased groundwater levels, water exhaustion, water pollution and deterioration of water quality. Integration of remote sensing with GIS for preparing various thematic layers, such as drainage density, (b) geomorphology, (c) lineament density, (d) land use/land cover, (e) soil type, (f) water bodies density, (g) normalized difference vegetation index (NDVI), (h) slope and (i) mean annual rainfall with assigned weightage in a spatial domain will support the identification of potential groundwater zones. Therefore, the present study focuses on the identification of groundwater potential zones in Keleghai river basin using the advanced technology of remote sensing, and GIS for the planning, utilization, administration, and management of groundwater resources.

\section{Study area}

The Keleghai river basin lies between $22^{\circ} 05^{\prime} 10^{\prime \prime} \mathrm{N}$ to $22^{\circ} 21^{\prime} 05^{\prime \prime} \mathrm{N}$ latitude and $87^{\circ} 05^{\prime} 09^{\prime \prime} \mathrm{E}$ to $87^{\circ} 51^{\prime} 03^{\prime \prime} \mathrm{E}$ longitude. The selected basin with an area of $1440 \mathrm{~km}^{2}$ and located in the north-western part of Purba and Paschim Medinipur district. It consists of 25 villages, which are the second order administrative units within the province (Fig. 1). This area has a subtropical with monsoon climate, an average annual precipitation $116 \mathrm{~mm}$ with the highest intensity of rainfall during June to September. Due to the monsoon, the total amount of rainfall in these four months account for more than a half of the total amount of the yearly rainfall in this area. Topography of the area represents elevations ranging from 4 to $102 \mathrm{~m}$, and $65 \%$ of the total area falls within $60-80 \mathrm{~m}$ altitude. About $70.21 \%$ of the total area falls under moderate to moderately steep slope $\left(5^{\circ}-20^{\circ}\right)$, indicating a potential zone for soil erosion. The analysis of the soil type reveals that the study area is predominantly covered by alluvial pain with clayey and alluvial coastal loamy soil (in the flood plains) at most of places. However, climate, slope, soils, vegetation cover and land management are the most important factors influencing groundwater availability, and population pressure leads to use of marginal lands and steep slopes which can accelerate recharge process of groundwater. The region has been suffering from fluctuating groundwater table, and therefore should be considered as a priority area for analysis groundwater conservation. A groundwater potential map can be incorporated to formulate effective management strategies for groundwater conservation in the area.

\section{Database and methods}

The groundwater status of an area depends upon the regional conditions of the area, such as climate, soil condition, land use/land cover, topography, lithology, etc. Therefore, to assess the potentiality of the area a range of evaluation criteria, objectives and attributes should be identified with respect to the problem situation (Rahman and Saha 2008). Based on field surveys, analysis of available information (Table 1) and combined professional expert judgment; the dominating nine (9) factors were assessed and determined such as (a) drainage density, (b) geomorphology, (c) lineament density, (d) land use/land cover, (e) soil type, (f) water bodies density, (g) normalized difference vegetation index (NDVI), (h) slope and (i) mean annual rainfall. In each thematic map, highest weight is given to the class that is most favourable, either to potential, or to quality and suitability of use, and lowest weight is given to the class that is least favourable. All the thematic maps related to groundwater potential zones were integrated and classified depending on the added weight factors determined in the analysis. In the same way, all thematic maps of groundwater quality were also integrated and classified. Finally, by integrating 


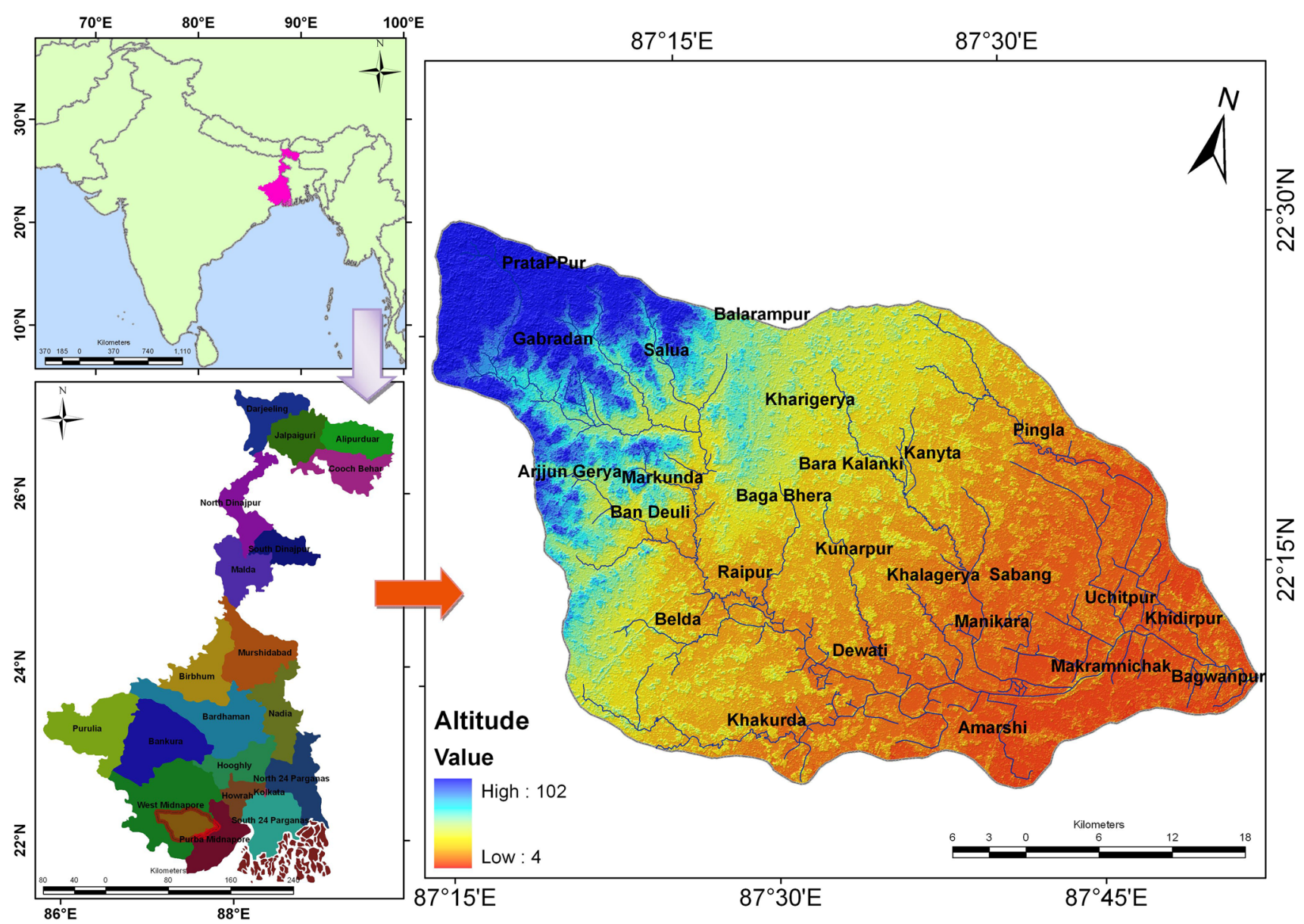

Fig. 1 Location map of study area and altitude

Table 1 Details of data used in groundwater potential analysis

\begin{tabular}{|c|c|c|c|}
\hline Data & Sources (URL) & Type & Time/period \\
\hline Digital elevation model & $\begin{array}{l}\text { http://gdem.ersdac.jspacesystems. } \\
\text { or.jp/search.jsp }\end{array}$ & Satellite-borne sensor ASTER & $\begin{array}{l}\text { ASTER GDEM V 2.0, 17th } \\
\text { October, } 2011\end{array}$ \\
\hline Satellite images & http://landsat.usgs.gov; earth.esa.int & $\begin{array}{l}\text { IIRS P6/Sensor-LISS- III and Landsat } 7 \\
\text { (Thematic Mapper }^{\mathrm{TM}} \text { ) }\end{array}$ & $\begin{array}{l}\text { WRS-Path }=139 \\
\text { WRS-Row }=045 \\
\text { 4th April, } 2011\end{array}$ \\
\hline Rainfall data & http://www.worldclim.org & Grid data & $1950-2010$ \\
\hline Soil map & http://www.nbsslup.in & Reference type & End report: AS3 229, 2005 \\
\hline Geomorphology & http://www.portal.gsi.gov.in & Reference type & 2010 \\
\hline Drainage networks & $\begin{array}{l}\text { http://www.surveyofindia.gov.in } \\
\text { http://earth.google.com }\end{array}$ & $\begin{array}{l}\text { Toposheet }(73 \mathrm{~N} / 3 ; 73 \mathrm{~N} / 4 ; 73 \mathrm{~N} / 7 ; 73 \mathrm{~N} / 8 \\
73 \mathrm{~N} / 11 \text { and } 73 \mathrm{~N} / 12) \text { and Google image }\end{array}$ & 1973 and 2011 \\
\hline
\end{tabular}

the groundwater potential zone classes with the groundwater quality and suitability classes, areas of both groundwater potential and groundwater quality and suitability were delineated. The complete work flow of methodology is given in Fig. 2.

The basic input is the pair wise comparison matrix of $n$ thematic layer constructed based on the Saaty's (1980) analytical hierarchy process (AHP) scaling ratios which could be of the order $(n \times n)$, and is in the matrix form as:

$A=\left[a_{i j}\right]$

where $i, j=1,2,3 \ldots n$. The matrix $A$ has generally the property of reciprocality and consistency. This is mathematically given as: 
Fig. 2 Flow chart of methodology used for deriving groundwater potential zones

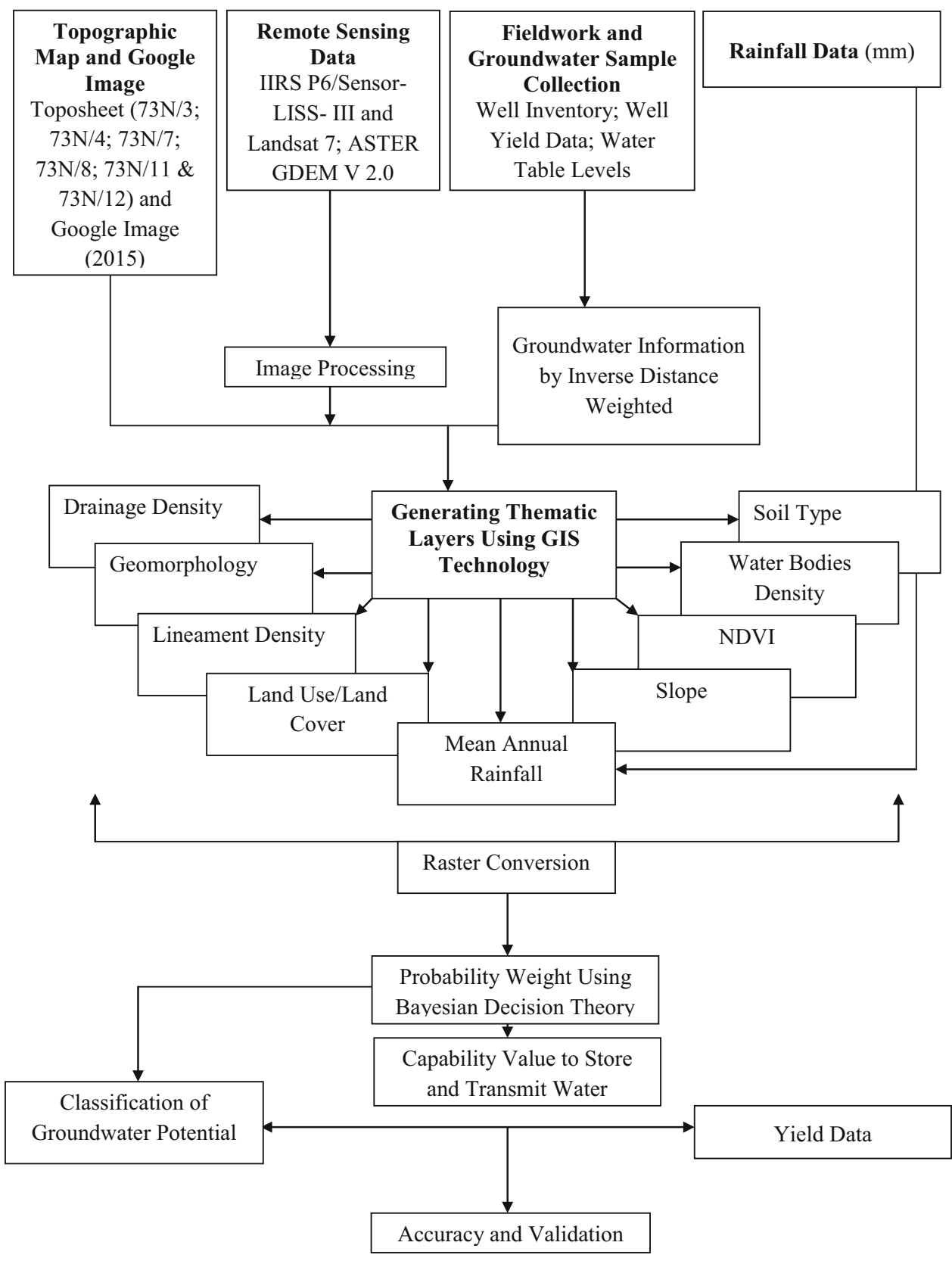

$a_{i j}=\frac{1}{a_{j i^{\prime}}}$

and

$a_{i j}=\frac{a_{i k}}{a_{j k}}$

For any $i, j$ and $k$. Thus, multiplying $A$ with weighting vector $W$ of order $(n \times 1)$ size yields:

$(A-n I) W=0$

where, $I$ is an identity matrix of order $(n \times n)$. According to the matrix theory, if the matrix $A$ has the property of consistency, the system of equations has a trivial solution. The matrix $A$ is, however, a judgement matrix and it may not be possible to determine the elements of $A$ accurately to satisfy the property of consistency. Therefore, it is estimated by a set of linear homogenous equations:

$A^{*} \times W^{*}={ }_{\max } W^{*}$

where, $A^{*}$ is the estimate of $A$, and $W^{*}$ is the corresponding priority vector and max is the largest eigen value for the matrix $A$. The above equation yields the weightages $W$ which are normalized to unity for further purpose.

After determining the weightages for the parameters, it is necessary to rank each category of the parameters for the 
suitability analysis. The ranks of individual categories are assigned in such a way that higher the rank, higher is the suitability and lesser are the limitations. For determining the inter-class/inter-map dependency, a probability weighted approach was adopted that allows a linear combination of probability weights of each thematic map $\left(W_{i}\right)$ with individual impact value (Sarkar and Doeta 2000). The thematic maps have been ranked in a scale of 1-9 depending upon their suitability to hold groundwater. The rank of each map has been converted to a probability weight using Bayesian Decision Theory (Haan 2002). Similarly, different categories of derived thematic maps were assigned scores in a numeric scale $1-9$, depending upon their capability to store and transmit water. These scores were again converted capability values (Fig. 4). This capability values $\left(c v_{i}\right)$ were then multiplied with the respective probability weight of each thematic map to arrive at the final weight map. Integration analysis was carried out using overlay-intersect method and a composite groundwater potential map was generated. The composite potential index was obtained by multiplying weightages with rank numbers of each category and summing up the values of all categories. This can be mathematically defined as:

$G W P=f\left(c v_{D_{d}}+G_{m o r}+L_{d}+L_{l u}+S_{t y}+W_{d}+N_{v}+S_{l}+R_{n}\right)$

where, $G P W$ refers to groundwater potential, $f$-function of, $D_{d}$-drainage density, $G_{m o r}$ geomorphology, $L_{d}$-lineament density, $L_{l u}$-land use/land cover, $S_{t y}$-soil type, $W_{d}$-water bodies density, $N_{v}$-normalized difference vegetation index (NDVI), $S_{l}$-slope, $R_{n}$-mean annual rainfall.

Groundwater potential map (index) values can be expressed as:

$G W P=\sum_{i=1}^{n} W_{i} \times c v_{i}$

where, $W_{i}$ map weight, $c v_{i}$ capability value. The algorithm used in the derivation of groundwater potential index $(G W I)$ as follows:

$$
\begin{aligned}
G W I= & 0.200 \times\left[c v_{D_{d}}\right]+0.156 \times\left[c v_{G_{m o r}}\right]+0.178 \times\left[c v_{L_{d}}\right] \\
& +0.133 \times\left[c v_{L_{l u}}\right]+0.111\left[c v_{S_{t y}}\right]+0.089 \\
& \times\left[c v_{W_{d}}\right]+0.067 \times\left[c v_{N_{v}}\right]+0.044 \times\left[c v_{S_{l}}\right] \\
& +0.022 \times\left[c v_{R_{n}}\right]
\end{aligned}
$$

where, $c v_{D_{d}}$ drainage density with capability value, $c v_{G_{m o r}}$ geomorphology with capability value, $c v_{L_{d}}$ lineament density with capability value, $c v_{L_{l u}}$ land use/land cover with capability value, $c v_{S_{t y}}$ soil type with capability value, $c v_{W_{d}}$ water bodies density with capability value, $c v_{N_{v}}$ normalized difference vegetation index (NDVI) with capability value, $c v_{S_{l}}$ slope with capability value, $c v_{R_{n}}$ mean annual rainfall with capability value.

The resultant final map indicates the potentiality of groundwater occurrence in the study area. This map was then classified into five categorise based on the groundwater potential index value.

\section{Ranking classes of various parameters}

The occurrence and movement of groundwater in an area is governed by several layers, such as (a) drainage density, (b) geomorphology, (c) lineament density, (d) land use/land cover, (e) soil type, (f) water bodies density, (g) normalized difference vegetation index (NDVI), (h) slope and (i) mean annual rainfall. These layers are as follows in Fig. 3:

\section{Drainage density}

Drainage density is defined as the closeness of spacing of stream channels. It is a measure of the total length of the stream segment of all orders per unit area. The drainage density is an inverse function of permeability. The less permeable a rock is, the less the infiltration of rainfall, which conversely tends to be concentrated in surface runoff. Drainage density of the study area is calculated using line density analysis tool in ArcGIS software. The study area has been grouped into five classes. These classes have been assigned to very low $\left(0-0.236 \mathrm{~km} / \mathrm{km}^{2}\right)$, low $\left(0.237-0.472 \mathrm{~km} / \mathrm{km}^{2}\right)$, moderate $\left(0.473-0.708 \mathrm{~km} / \mathrm{km}^{2}\right)$, high $\left(0.709-0.944 \mathrm{~km} / \mathrm{km}^{2}\right)$ and very high $(0.945-1.18 \mathrm{~km} /$ $\left.\mathrm{km}^{2}\right)$. High drainage density $\left(0.945-1.18 \mathrm{~km} / \mathrm{km}^{2}\right)$ is recorded in the southern parts (Raipur and Dewati) of the study area (Fig. 3a). The suitability of groundwater potential zones is indirectly related to drainage density because of its relation with surface runoff and permeability.

\section{Geomorphology}

The study area is underlain by fluvial origin, which is overlain by valley fill sediments and minor alluvium of recent age along the drainage courses. Alluvium quaternary sediments are spread almost in central part of the study area. The relief, slope, depth of weathering, type of weathered material, thickness of alluvium, nature of the deposited material and the overall assemblage of different landforms play in important role in defining the ground water regime, especially in the hard rock and the unconsolidated sediments. The erosional and depositional landforms identified in the study area are fluvial origin active flood plain, fluvial origin older flood plain, fluvial origin older alluvial plain and denudational origin-pediment and Pediplains complex (Fig. 3b). The North western parts of 
(a)

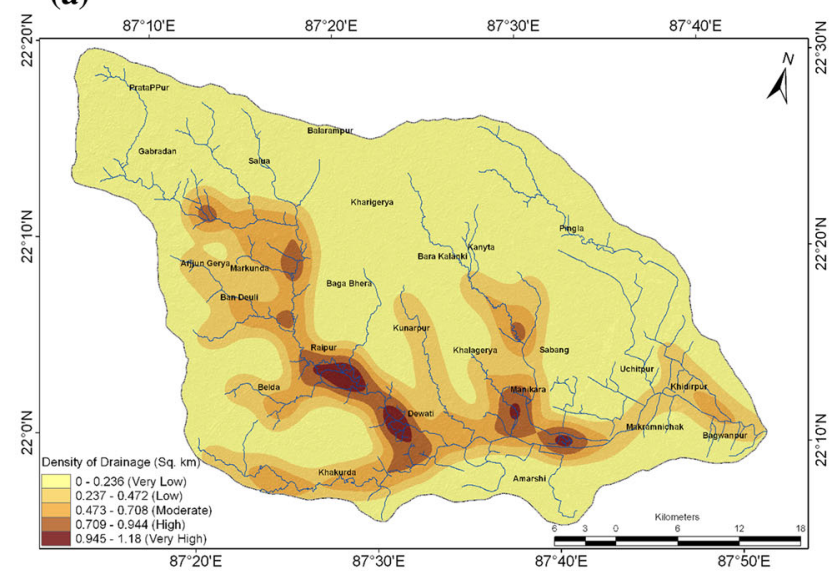

(c)

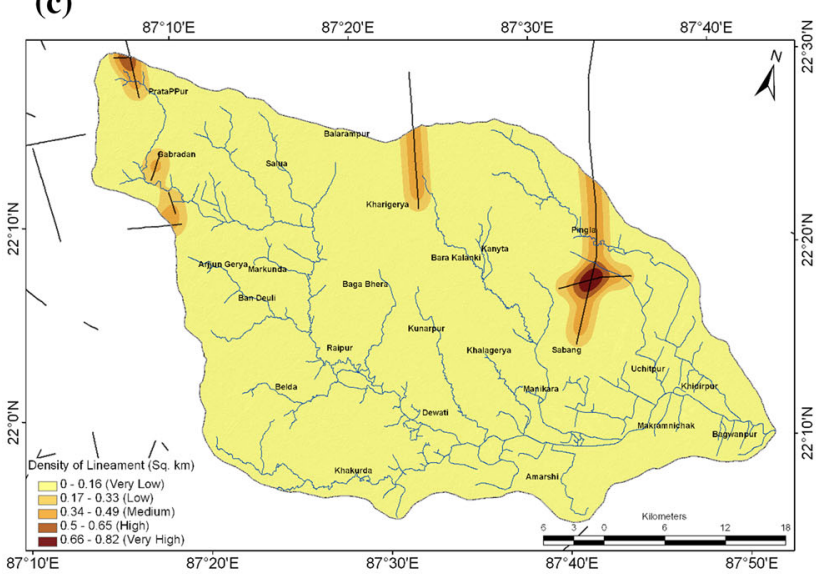

(e)

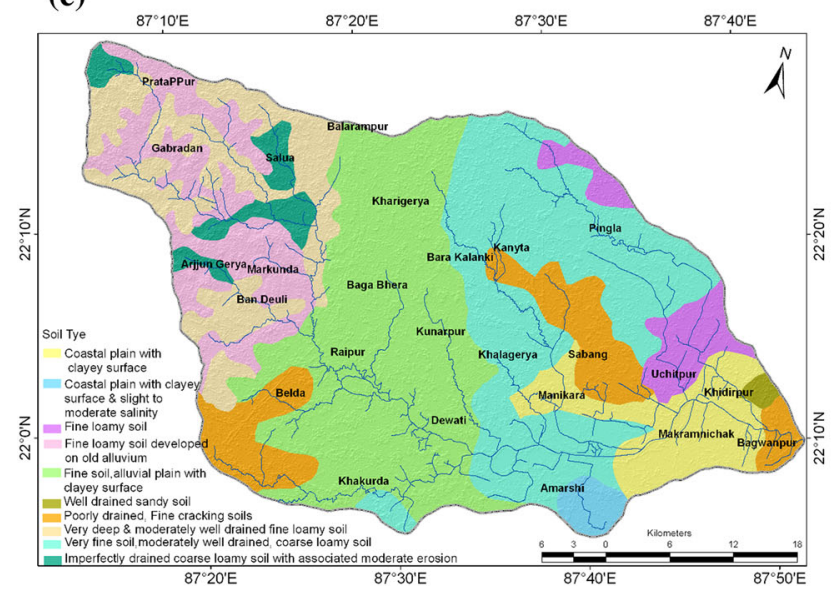

(b)

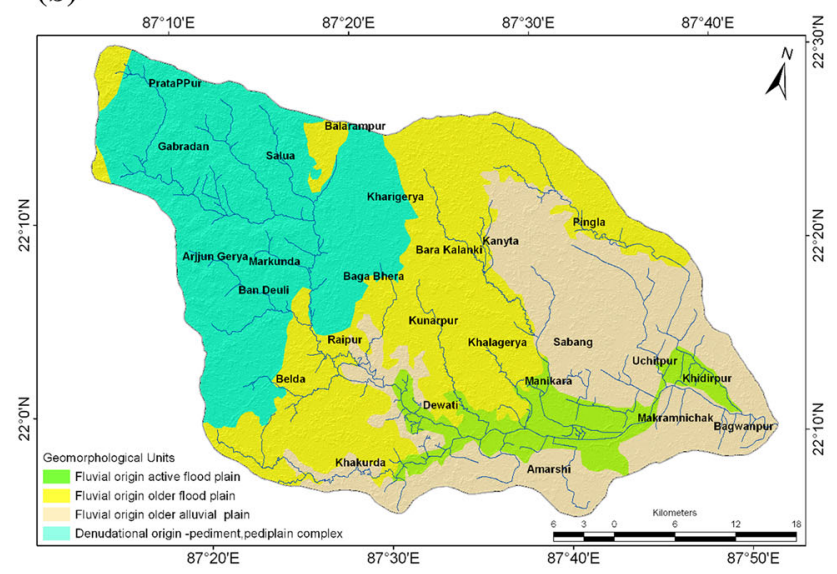

(d)
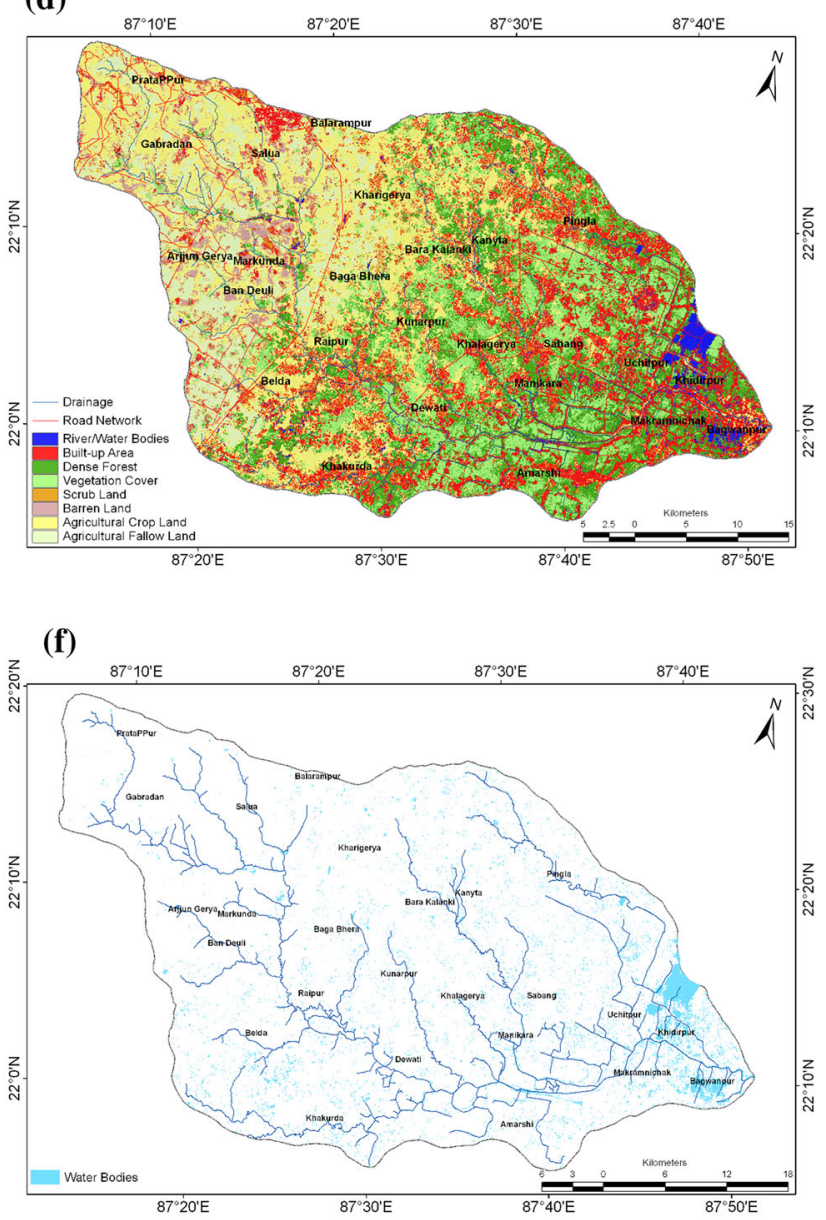

Fig. 3 Ground water potential condition factors a drainage density, b geomorphology, c lineament density, d land use/land cover, e soil type, f water bodies density, $\mathbf{g}$ normalized difference vegetation index (NDVI), $\mathbf{h}$ slope and $\mathbf{i}$ mean annual rainfall

the watershed is covered by linear ridges. The linear ridges and residual hill are the remanants of weathering and denudational action. Pediplains was formed on gently sloping plains or and covers mostly part of the study area. Flood plains were also found in the area.

\section{Lineament density}

Lineaments are structurally controlled linear or curvilinear features, which are identified from the satellite imagery by their relatively linear alignments. These features express 
(g)
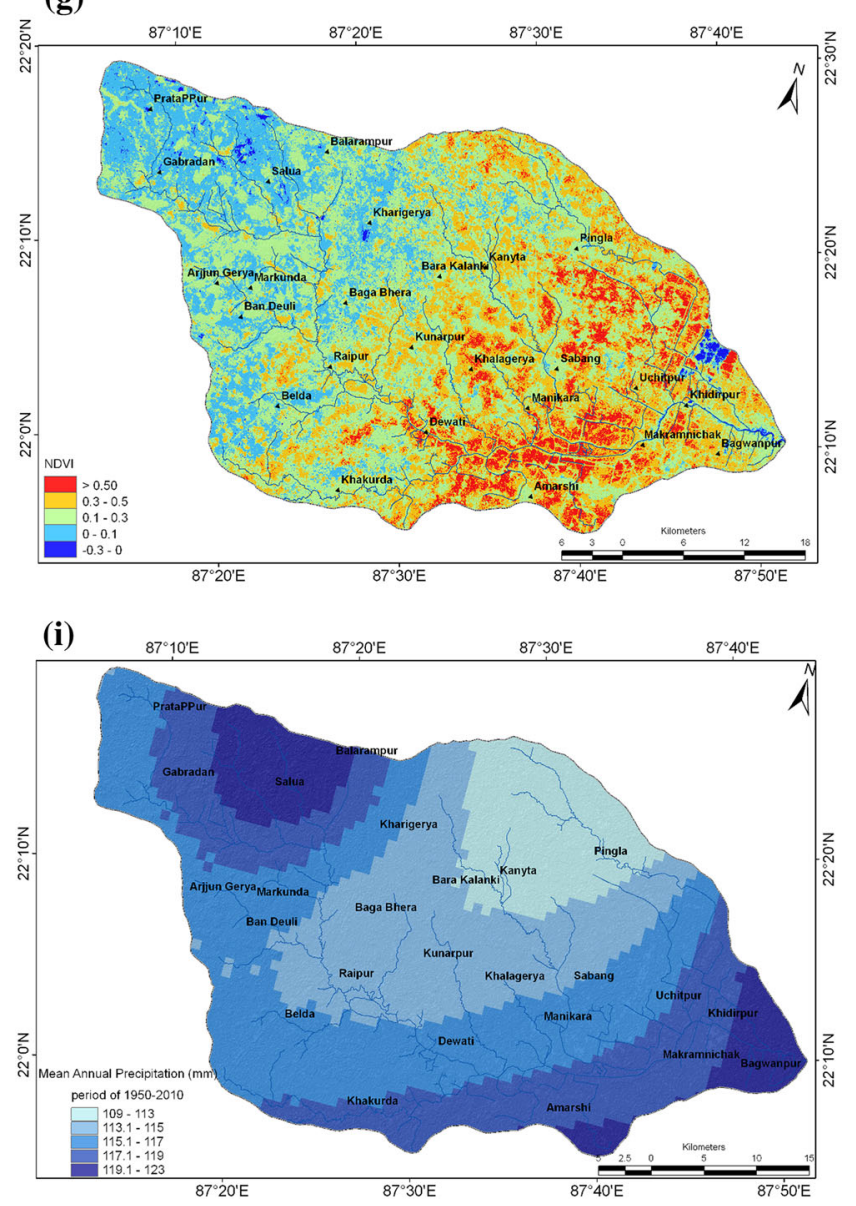

Fig. 3 continued

the surface topography of the underlying structural features. Lineaments represent the zones of faulting and fracturing resulting in increased secondary porosity and permeability. These factors are hydro-geologically very important as they provide the path ways for groundwater movement. Lineament density of an area can indirectly reveal the groundwater potential, since the presence of lineaments usually denotes a permeable zone. Areas with high lineament density are good for groundwater potential zones (Haridas et al. 1998). The lineament density map of the study area is shown in Fig. 3c, and it reveals that high lineament density is observed in between Pingla and Sabang in northern part of the study area with a value ranging from 0.66 to $0.82 \mathrm{~km} / \mathrm{km}^{2}$.

\section{Land use/land covers}

The major land-use type in the study area are road network, river/water bodies, built up area, dense forest, vegetation cover, scrub land barren land agricultural cropland and agricultural fallow land shown in Fig. 3d. These landuse (h)

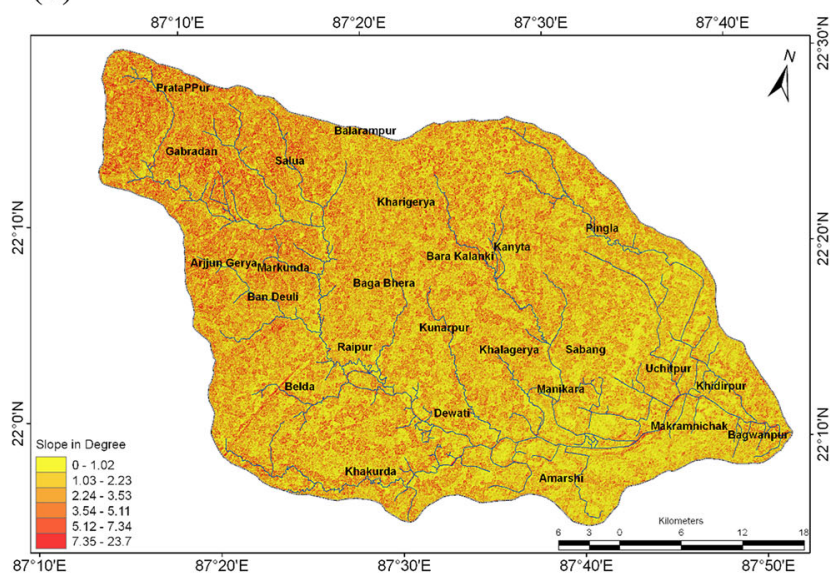

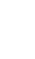
. 

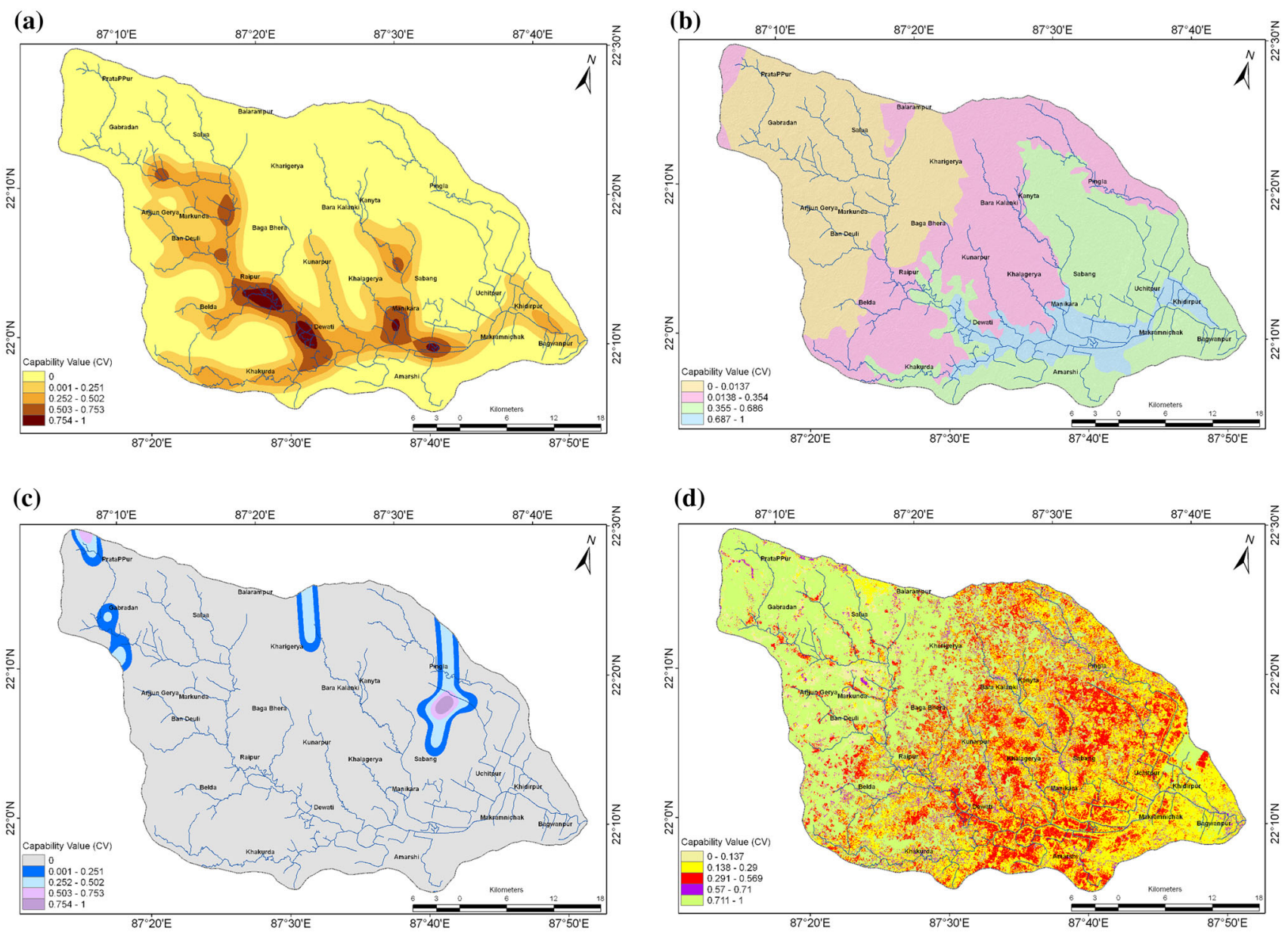

(d)

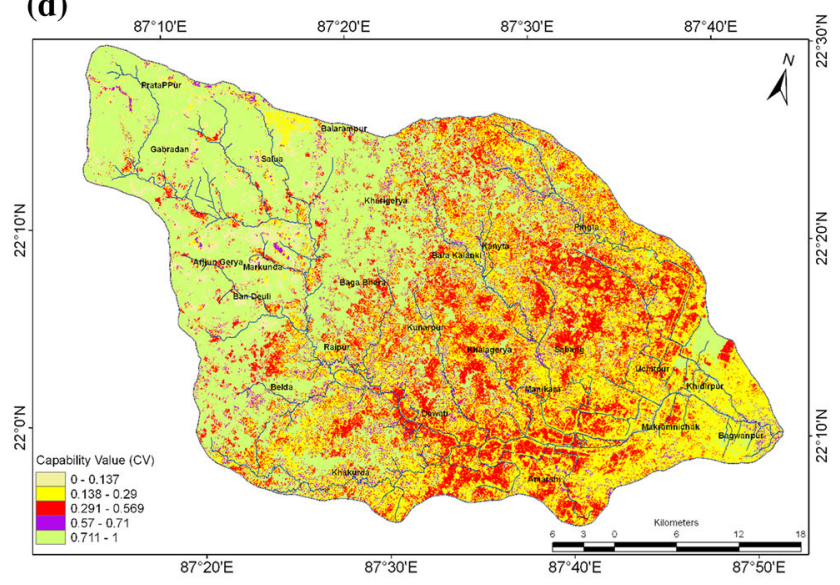

(e)
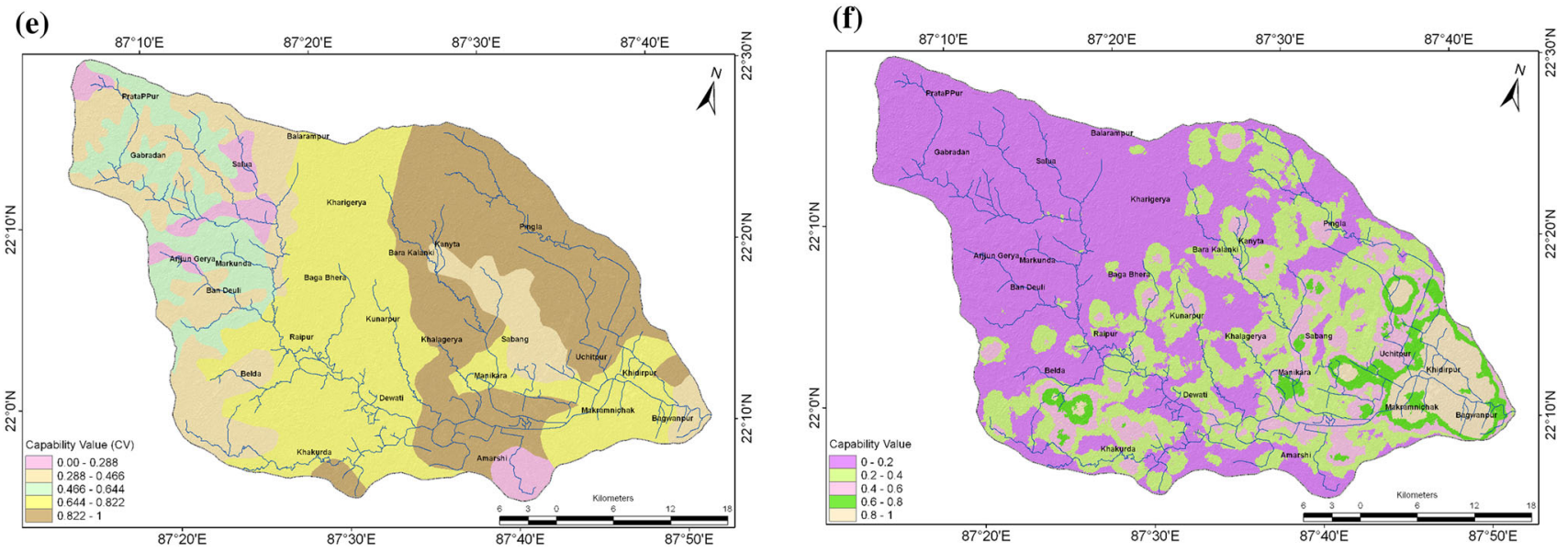

Fig. 4 Ground water potential condition factors a drainage density with capability value, b geomorphology with capability value, c lineament density with capability value, $\mathbf{d}$ land use/land cover with capability value, e soil type with capability value, $\mathbf{f}$ water bodies

density with capability value, $\mathbf{g}$ normalized difference vegetation index (NDVI) with capability value, $\mathbf{h}$ slope with capability value and i mean annual rainfall with capability value

theme as they are already considered in the drainage theme. Finally, the thematic layer was grouped into five classes. These classes have been assigned to very low $\left(0-3.9 \mathrm{~km}^{2}\right)$, low (3.91-6.68 km²), moderate $\left(6.69-9.79 \mathrm{~km}^{2}\right)$, high

$\left(9.80-14.10 \mathrm{~km}^{2}\right)$ and very high $\left(14.2-31.3 \mathrm{~km}^{2}\right)$. Highest water bodies density $\left(14.2-31.3 \mathrm{~km}^{2}\right)$ is found in the eastern parts (Khidirpur, Bhagwanpur and Makramnichak) of the study area (Fig. 6). The suitability of groundwater 

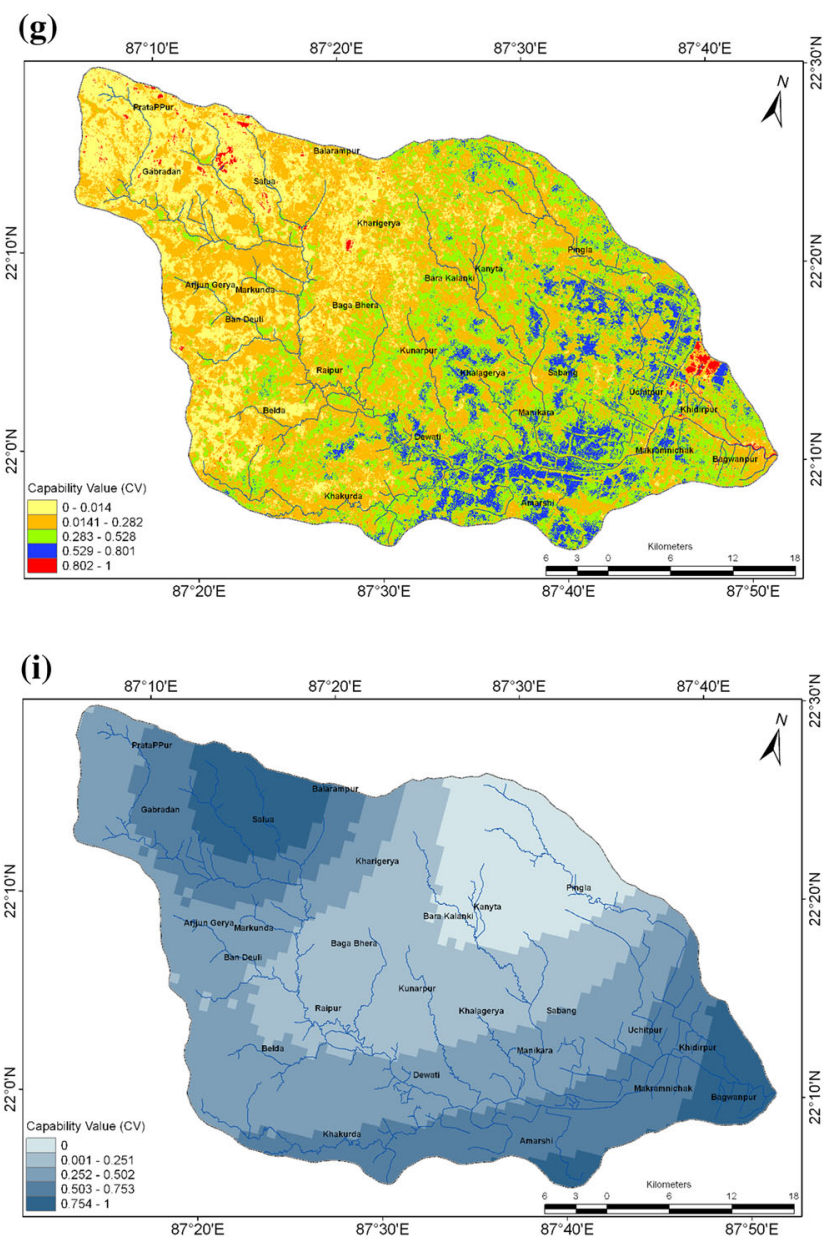

Fig. 4 continued

potential zones is directly related to surface water bodies because of its relation with surface runoff and permeability in Fig. 3f.

\section{Normalized difference vegetation index (NDVI)}

It is universally accepted that satellite derived normalized difference vegetation index (NDVI) is an important index to assess crop stage/condition. Crop condition at any given time during its growth is influenced by complex interactions of weather, soil moisture, and soil and crop types. The analysis of normalized difference vegetation index (NDVI) is regarded as the rough estimation of vegetation amount present and ground water prospect over the space in Fig. 3g.

\section{Slope}

Slope is an important factor for the identification of groundwater potential zones. Higher degree of slope results

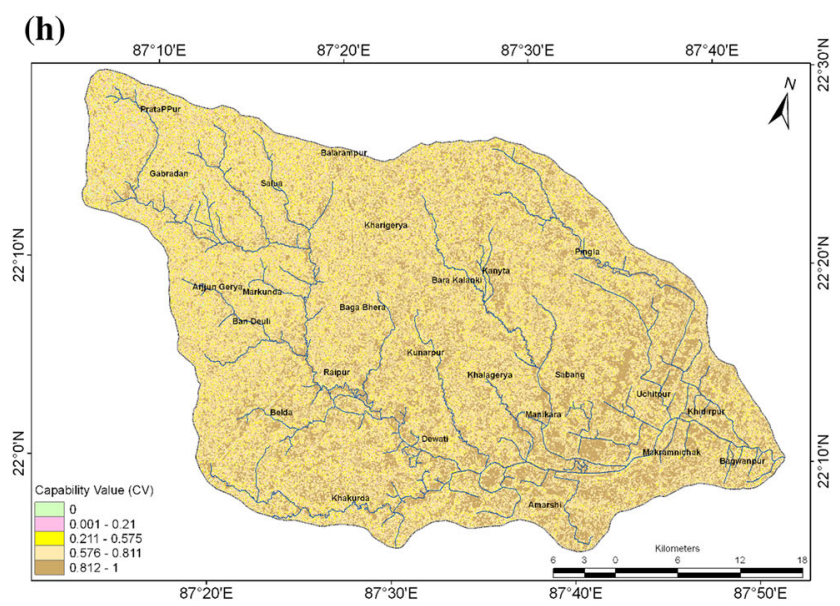

in rapid runoff and increased erosion rate with feeble recharge potential (Magesh et al. 2011a, b). The slope map of the study area was prepared based on ASTER data using the spatial analysis tool in ArcInfo 9.3. Slope grid is identified as "the maximum rate of change in value from each cell to its neighbours" (Burrough 1986). Based on the slope, the study area can be divided into four slope classes. The areas having $0^{\circ}-1.2^{\circ}$ slope fall into the very good category because of the nearly flat terrain and relatively high infiltration rate. The areas with $1.3^{\circ}-2.23^{\circ}$ slope are considered as good for groundwater storage due to slightly undulating topography with some runoff. The areas having a slope of $2.24^{\circ}-3.53^{\circ}$ cause relatively high runoff and low infiltration, and hence are categorized as poor and the areas having a slope $3.53^{\circ}-5.11^{\circ}$ are considered as very poor due to higher slope and runoff. Whereas the area having slope $5.12^{\circ}-7.34^{\circ}$ and $7.35^{\circ}-23.7^{\circ}$ are considered as extremely poor and unsuitable respectively due to higher steep slope and does not favour to direct percolation. Figure $3 \mathrm{~h}$ illustrates the slope map of the study area. 


\section{Mean annual rainfall}

The mean annual rainfall of the study area is around $116 \mathrm{~mm}$ for the long term average (1950-2010). The south-west monsoon accounts for $21 \%$, north-east monsoon $46 \%$, winter $6 \%$ and summer $27 \%$ of total rainfall (Fig. 3i). The study area depends mainly on north-east monsoon rains, which are brought by the troughs of low pressure establishing in south Bay of Bengal between October and December. Rainfall distribution along with the slope gradient directly affects the infiltration rate of runoff water hence increases the possibility of groundwater potential zones.

\section{Results and discussion}

\section{Delineating the groundwater potential zone by GIS and Overlay analysis}

The groundwater potential zones for the study area were generated through the integration of various thematic maps viz., drainage density, geomorphology, lineament density, landuse/land cover, soil type, water bodies density, normalized difference vegetation index (NDVI), slope, mean annual rainfall using remote sensing and GIS techniques. The demarcation of groundwater potential zones for the study area was made by grouping of the interpreted layers through weighted multi conditioning factor and finally assigned different potential zones. The groundwater potential zone of this study area can be divided into five grades, namely very good, good, moderate, poor and very poor. The groundwater potential map (Fig. 5) demonstrates that the excellent groundwater potential zone is concentrated in the south-eastern and south-western region of the study area due to the abundance distribution of very fine soil, alluvial plain with clayey surface, moderately well drained and coarse loamy soil. Similar results are reported by Shankar and Mohan (2006); Prasad et al. (2008). This indicates that, soil type and slope plays a vital role in groundwater augmentation. Moreover, the concentration of drainage density and lineament density also helps the infiltration ability of the groundwater recharge system. About $3.64 \%$ of the total area falls under the 'very poor' zone, $18.65 \%$ falls under 'poor' zone, $38.25 \%$ falls under 'moderate' groundwater potential zone, and $29.25 \%$ and $10.20 \%$ of the study area fall under 'good' and 'very good' potential zone respectively. Finally, the cumulative effect of the weighted conditioning factors through overlay analysis in GIS platform revealed the mapping of groundwater potential zones in the study area.

\section{Spatial distribution and pattern of groundwater potential zones}

Nine factors like, drainage density, geomorphology, lineament density, landuse/land cover, soil type, water bodies density, normalized difference vegetation index (NDVI), slope, mean annual rainfall to AHP evaluation by following Saaty's (1980) importance scale. The summation of the product of all the map weights of the thematic layer, each with the related capability value of corresponding
Fig. 5 Spatial pattern of ground water potential in Keleghai river basin

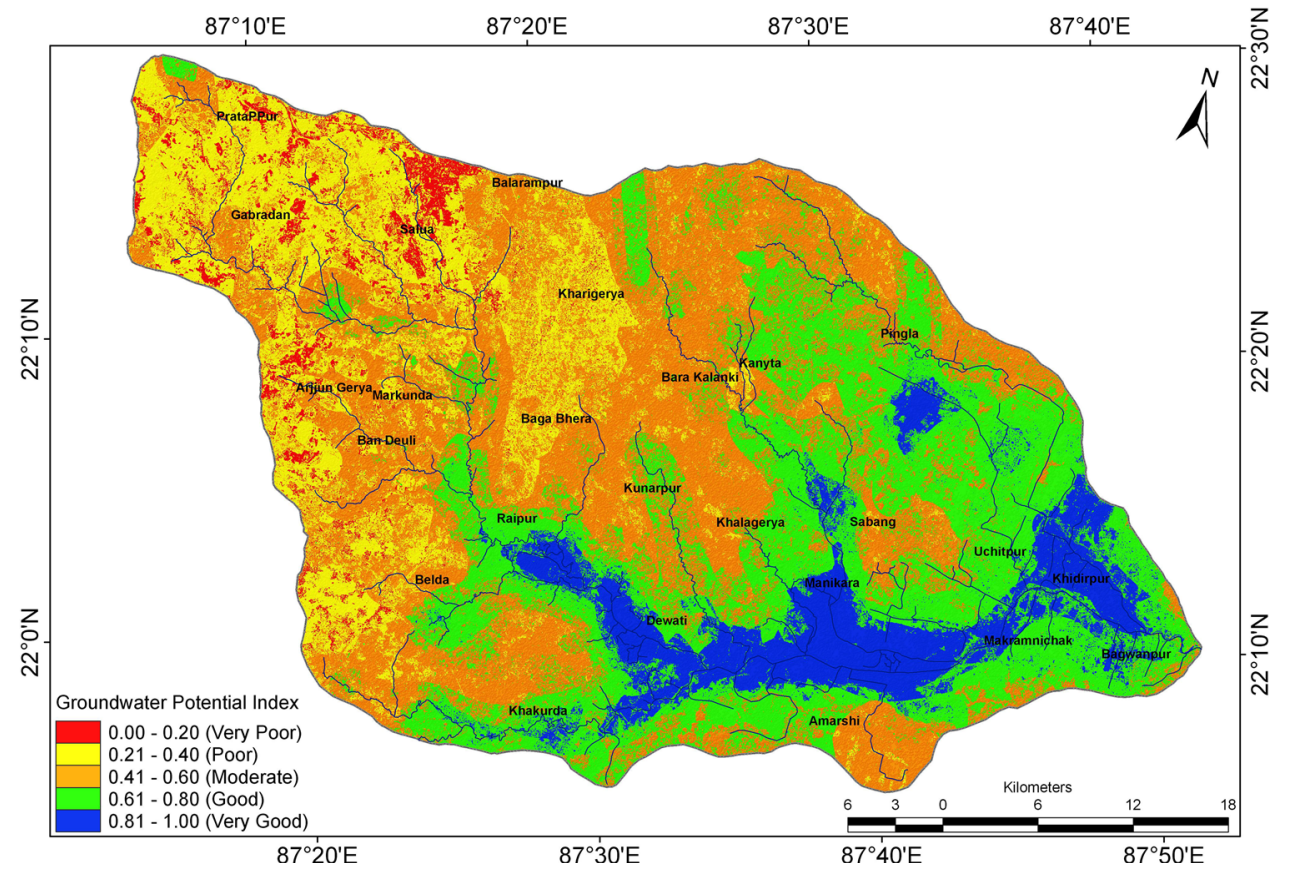


Table 2 Thematic layer weight and capability value for groundwater potential zones in the Keleghai river basin

\begin{tabular}{|c|c|c|c|c|c|}
\hline \multirow[t]{2}{*}{ Thematic layer } & \multirow[t]{2}{*}{ Class domain of effect } & \multirow[t]{2}{*}{ Preference rank } & \multicolumn{2}{|c|}{ Thematic assigned } & \multirow[t]{2}{*}{ Capability value $\left(c v_{i}\right)$} \\
\hline & & & Map rank & Map weight $\left(w_{i}\right)$ & \\
\hline \multirow[t]{8}{*}{ Landuse/land cover } & Barren land & 1 & 4 & 0.133 & 0.00 \\
\hline & Built-up area & 2 & & & 0.14 \\
\hline & Dense forest & 3 & & & 0.29 \\
\hline & Vegetation cover & 4 & & & 0.43 \\
\hline & Scrub land & 5 & & & 0.57 \\
\hline & Agriculture crop land & 6 & & & 0.71 \\
\hline & Agriculture fallow land & 7 & & & 0.86 \\
\hline & River/water bodies & 8 & & & 1.00 \\
\hline \multirow[t]{4}{*}{ Geomorphology } & $\begin{array}{l}\text { Denudational origin-pediment, pediplain } \\
\text { complex }\end{array}$ & 1 & 2 & 0.156 & 0.00 \\
\hline & Fluvial origin older flood plain & 2 & & & 0.33 \\
\hline & Fluvial origin older alluvial plain & 3 & & & 0.67 \\
\hline & Fluvial origin active flood plain & 4 & & & 1.00 \\
\hline \multirow[t]{5}{*}{ Lineament density } & Very low & 1 & 3 & 0.178 & 0.00 \\
\hline & Low & 2 & & & 0.25 \\
\hline & Medium & 3 & & & 0.50 \\
\hline & High & 4 & & & 0.75 \\
\hline & Very high & 5 & & & 1.00 \\
\hline \multirow[t]{5}{*}{ Drainage density } & Very low & 1 & 1 & 0.200 & 0.00 \\
\hline & Low & 2 & & & 0.25 \\
\hline & Medium & 3 & & & 0.50 \\
\hline & High & 4 & & & 0.75 \\
\hline & Very high & 5 & & & 1.00 \\
\hline \multirow[t]{10}{*}{ Soil type } & $\begin{array}{l}\text { Very fine soil, moderately well drained, } \\
\text { coarse loamy soil }\end{array}$ & 1 & 5 & 0.111 & 0.00 \\
\hline & $\begin{array}{l}\text { Imperfectly drained coarse loamy soil } \\
\text { with associated moderate erosion }\end{array}$ & 2 & & & 0.11 \\
\hline & $\begin{array}{l}\text { Coastal plain with clayey surface and } \\
\text { slight to moderate salinity }\end{array}$ & 3 & & & 0.22 \\
\hline & Poorly drained, fine cracking soils & 4 & & & 0.33 \\
\hline & $\begin{array}{l}\text { Very deep and moderately well drained } \\
\text { fine loamy soil }\end{array}$ & 5 & & & 0.44 \\
\hline & $\begin{array}{l}\text { Fine loamy soil developed on old } \\
\text { alluvium }\end{array}$ & 6 & & & 0.56 \\
\hline & $\begin{array}{l}\text { Fine soil, alluvial plain with clayey } \\
\text { surface }\end{array}$ & 7 & & & 0.67 \\
\hline & Coastal plain with clayey surface & 8 & & & 0.78 \\
\hline & Fine loamy soil & 9 & & & 0.89 \\
\hline & Well drained sandy soil & 10 & & & 1.00 \\
\hline \multirow[t]{5}{*}{ Mean annual rainfall } & $109-113$ & 1 & 9 & 0.022 & 0.00 \\
\hline & $113-115$ & 2 & & & 0.25 \\
\hline & $115-117$ & 3 & & & 0.50 \\
\hline & $115-119$ & 4 & & & 0.75 \\
\hline & $119-123$ & 5 & & & 1.00 \\
\hline \multirow[t]{5}{*}{ NDVI } & $0-0.1$ & 1 & 7 & 0.067 & 0.00 \\
\hline & $0.1-0.3$ & 2 & & & 0.25 \\
\hline & $0.3-0.5$ & 3 & & & 0.50 \\
\hline & $>0.50$ & 4 & & & 0.75 \\
\hline & $-0.3-0$ & 5 & & & 1.00 \\
\hline
\end{tabular}


Table 2 continued

\begin{tabular}{|c|c|c|c|c|c|}
\hline \multirow[t]{2}{*}{ Thematic layer } & \multirow[t]{2}{*}{ Class domain of effect } & \multirow[t]{2}{*}{ Preference rank } & \multicolumn{2}{|c|}{ Thematic assigned } & \multirow[t]{2}{*}{ Capability value $\left(c v_{i}\right)$} \\
\hline & & & Map rank & Map weight $\left(w_{i}\right)$ & \\
\hline \multirow[t]{6}{*}{ Slope } & $7.35-23.7$ & 1 & 8 & 0.044 & 0.00 \\
\hline & $5.12-7.34$ & 2 & & & 0.20 \\
\hline & $3.54-5.11$ & 3 & & & 0.40 \\
\hline & $2.24-3.53$ & 4 & & & 0.60 \\
\hline & $1.03-2.23$ & 5 & & & 0.80 \\
\hline & $0-1.02$ & 6 & & & 1.00 \\
\hline \multirow[t]{5}{*}{ Water bodies density } & Very low & 1 & 6 & 0.089 & 0.00 \\
\hline & Low & 2 & & & 0.25 \\
\hline & Medium & 3 & & & 0.50 \\
\hline & High & 4 & & & 0.75 \\
\hline & Very high & 5 & & & 1.00 \\
\hline
\end{tabular}

Table 3 Microzonation of groundwater potential zones (after integration all thematic maps)

\begin{tabular}{lcccc}
\hline $\begin{array}{l}\text { Ground water potential } \\
\text { index }\end{array}$ & $\begin{array}{l}\text { Pixel in } \\
\text { domain }\end{array}$ & $\begin{array}{l}\text { Percentage of the } \\
\text { area }\end{array}$ & $\begin{array}{l}\text { Area } \\
\text { (sq.km) }\end{array}$ & Area under ground water potential index \\
\hline $0.00-0.20$ (very poor) & 77140 & 3.64 & 69.43 & $\begin{array}{c}\text { Pratappur, Gobradan, Salua, Arjungeria, Markunda, } \\
\text { Bandeuli }\end{array}$ \\
$0.21-0.40$ (poor) & 395004 & 18.65 & 355.50 & $\begin{array}{l}\text { Balarampur, Kharigeria, Baga Bhera, Belda, khalageria } \\
0.41-0.60 \text { (moderate) }\end{array}$ \\
$0.61-0.80$ (good) & 619334 & 29.25 & 728.94 & Bara Kalanki, Kunarpur, Kantya \\
$0.81-1.00$ (very good) & 216078 & 10.20 & 557.40 & Pingla, Khakurda, Raipur, Sabang, Uchitpur, Amarshi \\
\hline
\end{tabular}

Table 4 Hydromorphogeological characteristics in Keleghai river basin, India

\begin{tabular}{|c|c|c|}
\hline Unit & Characteristics & $\begin{array}{l}\text { Groundwater } \\
\text { prospects }\end{array}$ \\
\hline $\begin{array}{l}\text { Fluvial origin and active flood } \\
\text { plain }\end{array}$ & $\begin{array}{l}\text { Nearly level surface along the river courses with gravel, coarse-fine sand, clay etc., at } \\
\text { various locations coconut gardens and plantations are present }\end{array}$ & $\begin{array}{l}\text { Good to very } \\
\text { good }\end{array}$ \\
\hline $\begin{array}{l}\text { Fluvial origin and older flood } \\
\text { plain }\end{array}$ & $\begin{array}{l}\text { Away from river banks; gentle slopes with more vegetation. Weathered zones thickness } \\
\text { ranges from } 1 \text { to } 1.5 \mathrm{~m} \text {. Along silted, weathered zone thickness is more than } 2 \mathrm{~m}\end{array}$ & $\begin{array}{l}\text { Moderate to } \\
\text { good }\end{array}$ \\
\hline $\begin{array}{l}\text { Fluvial origin older alluvial flood } \\
\text { plain }\end{array}$ & $\begin{array}{l}\text { Gentle to moderate slope with sparse vegetation. Weathered zone thickness is less than } \\
1.5 \mathrm{~m} \text {. Along river channel weathered zone thickness is greater than } 0.5 \mathrm{~m}\end{array}$ & $\begin{array}{l}\text { Moderate to } \\
\text { poor }\end{array}$ \\
\hline $\begin{array}{l}\text { Denudational origin pediment- } \\
\text { pediplains complex }\end{array}$ & $\begin{array}{l}\text { A group of massive residual water divide with resistant some rock bodies, with medium to } \\
\text { high relief. Moderate slopes with a veneer of detritus and broad undulating rock floor. } \\
\text { Denudational exposures are seen at some places }\end{array}$ & $\begin{array}{l}\text { Poor to very } \\
\text { poor }\end{array}$ \\
\hline
\end{tabular}

categories (Table 2), finally depicts the groundwater potential zones. For this, the polygons in each of the nine thematic layers were overlaid by using intersect method of map overlay option in GIS.

Accordingly, the resultant polygons that were derived out of the overlaid theme by using the weighted value reflect all the nine factors that influence the groundwater potential of an area. The spatial distribution of all these categories of groundwater potential zones is depicted in
Fig. 5 and Table 3. Very good zones of groundwater potential occur in places where all the nine themes are more favorable to groundwater. From the figure, it is clear that very good groundwater potential category is seen in Dewati, Khidirpur, Makranichak, Bagwanpur and Manikara with rich surface water bodies and high drainage density with perennial flow that enhance the infiltration whereby the area becomes potential to groundwater storage. The second category of zones with good groundwater 
potential is predominantly seen all over Pingla, Khakurda, Raipur, Sabang, Uchitpur and Amarshi in the present study area. On the other hand, moderate as well as poor groundwater potential categories of zones were notably seen in Bara Kalanki, Kunarpur, Kantya and Balarampur, Kharigeria, Baga Bhera, Belda, Khalageria respectively. A few pockets of very poor groundwater potential zones were found in Pratappur, Gobradan, Salua, Arjjungeria, Markunda and Bandeuli, wherein dense area of settlements occurs. In fact, the northwestern part of the study area, having the geomorphic unit of ridge valley complex with dense lineaments and granite rock group, registered mostly moderate groundwater potential. Even though this region receives very high rainfall, the occurrence of dense lineaments and forest land use with porous soil. The groundwater potential is notably moderate due to the steep slopes of the terrain with fine drainage density. The southwestern side, which is of moderate slope with predominant upland geomorphic unit, has moderate to good groundwater potential. Similar is the case with regard to the southwestern region with high slope, which have upland geomorphic unit under laid by a variety of rocks belonging to different geomorphic units. This area with spacing drainage density and agricultural land use notably influence infiltration capacity, whereby this zone has a poor groundwater potential due to high slope aspect. In the southern region, even though the geomorphic units is of composite slope with fine soil, alluvial plain with clayey surface as silted bedrocks increases the infiltration of surface water to the ground; and the drainage density is moderate with loamy soil and agricultural land use, and so the groundwater potential of this zone is good. The southeastern regions have a favorable unit namely, valley fills, very fine soil, moderately well drained fine loamy soil with notable pediments and gentle to very gentle slope and therefore contributes to good groundwater potential. In spite of their silted bedrock with moderate rainfall, these areas have good groundwater potential. It is to be noted that the dense built-up area of this region like Balarampur, Gabradan and Arjjun Gerya have poor groundwater potential.

Hydromorphogeological characteristics in Keleghai river basin is shown in Table 4. Almost all the areas of Keleghai river basin except upper catchment portion are of gentle slope to nearly level, with moderate to high rainfall. The predominant land use here is dense forest and vegetation cover. Pediments with five alluvial to loamy soils dominate in this region thereby increasing the groundwater potential. Still, the groundwater potential is moderate to poor except for the surface water bodies and along the river course. In the coastal plain region, the rainfall and geomorphic unit namely the buried pediment, favor groundwater potential. The piedmont zone of northeastern parts with moderately dense lineaments
(Pingla fault) in the catchment area, moderate drainage density and loamy soil favour groundwater whereby the groundwater potential is very good. In the basin region, the geomorphic units, lineaments, drainages and slope favour groundwater potential; but imperfect coarse loamy soil with associated moderate erosion in which the infiltration is low brings the region under moderate to poor groundwater potential zone. The eastern region shows moderate to good groundwater potential due to the favourable geomorphic unit and the river course. Thus, various factors influence the groundwater potential of the study area, showing disparity in the distribution and pattern of groundwater.

The groundwater potential index obtained and it has been further validated. The predictive power of the potential index map has been tested by analyzing their success rate and prediction rate Curves (Chung and Fabbri 2003). This comparison has allowed verifying the spatial distribution of the groundwater areas in the potentiality ranked levels (Conoscenti et al. 2008). The calculation of the success rate and prediction rate curves for the Keleghai river basin is shown in Fig. 6. They have very similar shape, showing a high gradient in the first part and smoothly decrease monotonically. The prediction curve shows that $76.32 \%$ of the total groundwater area of the validation set falls within $15.32 \%$ of the most potential areas (Fig. 6). This result confirms both the validity of the potential method and the high spatial correlation between predisposing factors used for the analysis and the groundwater. Furthermore, the validation procedure results show that the predictive power of the model is generally satisfactory; therefore, about $93.21 \%$ of the groundwater area of the validation set is correctly classified falling in good

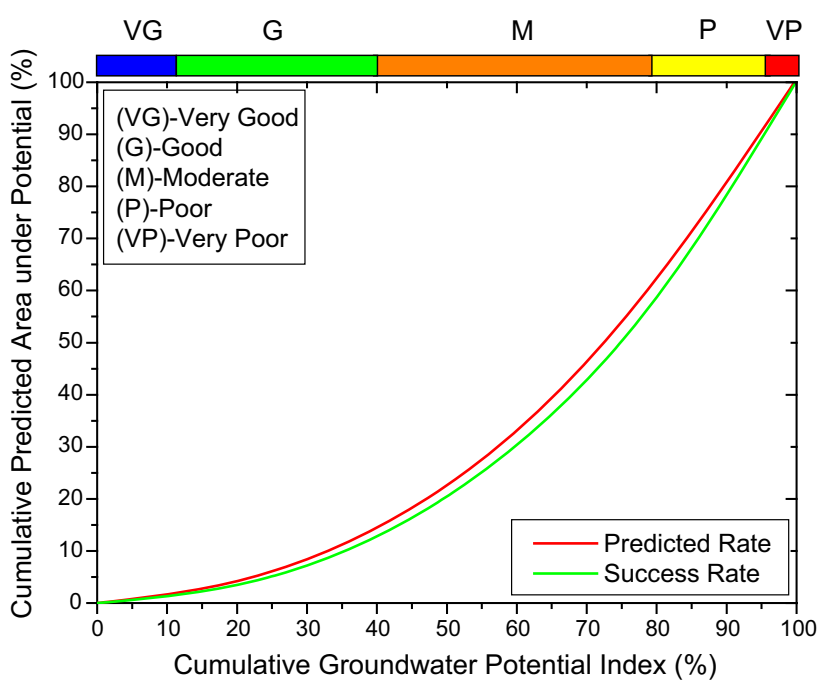

Fig. 6 Prediction rate and success rate curves that representing the accuracy of the area belong groundwater potential model 
and very good potential classes. This good result could be over weighted if researcher considers that the predisposing factors could have some relationship between each other.

\section{Conclusions}

From the previously mentioned studies related to the use of RS and GIS in groundwater mapping, it could be concluded that groundwater mapping is one of the main tools for efficient and controlled development of groundwater resources. These maps are used by engineers, planners and decision makers to allocate, develop and manage groundwater within a national water policy. Integrated RS and GIS techniques prove to be rather satisfactory options for groundwater mapping in different regions of Keleghai river basin. Delineating the groundwater potential zones in Keleghai river basin using remote sensing, GIS and AHP techniques is found efficient to minimize the time, labour and money and thereby enables quick decision-making for sustainable water resources management. Satellite imageries, topographic maps and conventional data were used to prepare the thematic layers of drainage density, geomorphology, lineament density, landuse/land cover, soil type, water bodies density, normalized difference vegetation index (NDVI), slope, mean annual rainfall. The various thematic layers are assigned proper weightage through AHP technique and then integrated in the GIS environment to prepare the groundwater potential zone map of the study area. According to the groundwater potential zone map, Keleghai river basin is categorized into five different zones, namely very good, good, moderate, poor, and very poor. The results of the present study can serve as guidelines for planning future artificial recharge projects in the study area in order to ensure sustainable groundwater utilization. This is an empirical method for the exploration of groundwater potential zones using remote sensing and GIS, and it succeeds in proposing potential sites for groundwater zones. This method can be widely applied to a vast area with rugged topography for the exploration of suitable sites.

From these studies, the following concluding remarks could be highlighted:

- Integrated RS-GIS techniques and AHP are useful in delineating favourable areas for well establishment using various geo-informative thematic maps.

- Modeling approach is applied to integrate the physical and geologic factors governing groundwater potentiality in a map form showing spatial data for areas with different responses to groundwater potentiality in the Keleghai river basin.
- As a future approach, within the field of groundwater mapping in Keleghai river basin, it is highly recommended to update the detailed hydro-geological maps of Keleghai river basin at a scale of 1:100,000 using RS and GIS techniques. Maps updating is recommended for assessing the actual short and long-term changes of groundwater regime caused by over pumping and population growth needs in these areas.

- Produce detailed groundwater maps of the Keleghai river basin for the purpose of supporting future development plans. Moreover, Radar images may provide significant advantages for groundwater mapping in this area.

- Much more RS and GIS based groundwater research with field investigations may be tried to effectively exploit the current and expanding potential of the technologies.

Acknowledgments This manuscript was considerably improved through comments and suggestions of anonymous referees and the editors. The authors are thankful to Survey of India (SOI), Kolkata, Geological Survey of India (GSI), Kolkata and National Bureau of Soil Survey and Land Use Planning (NBSS\&LUP), Nagpur for providing different data and information for the study area.

\section{References}

Burrough PA (1986) Principles of geographical information systems for land resources assessment. Oxford University Press, New York, p 50

Chowdhury A, Jha MK, Chowdary VM (2010) Delineation of groundwater recharge zones and identification of artificial recharge sites in West Medinipur district, West Bengal, using RS, GIS and MCDM techniques. Environ Earth Sci 59:1209e 1222

Chung CF, Fabbri AG (2003) Validation of spatial prediction models for landslide hazard mapping. Nat Hazards 30:451-472

Conoscenti C, Di Maggio C, Rotigliano E (2008) Soil erosion susceptibility assessment and validation using a geostatistical multivariate approach: a test in Southern Sicily. Nat Hazards 46:287-305

Dar IA, Sankar K, Dar MA (2010) Deciphering groundwater potential zones in hard rock terrain using geospatial technology. Environ Monit Assess 173:597e610

Das D (2000) GIS application in hydrogeological studies. http://www. gisdevelopment.net/application/nrm/water/overview/wato0003. htm. Accessed Mar 2010

Das S, Behera SC, Kar A, Narendra P, Guha S (1997) Hydrogeomorphological mapping in groundwater exploration using remotely sensed datadA case study in Keonjhar District, Orissa. J Indian Soc Remote Sens 25:247e259

Ganapuram S, Kumar G, Krishna I, Kahya E, Demirel M (2008) Mapping of groundwater potential zones in the Musi basin using remote sensing and GIS. Adv Eng Softw 40:506e518

Haan CT (2002) Statistical methods in hydrology, 2nd edn. Iowa State University Press, Ames, Iowa

Haridas VR, Aravindan S, Girish G (1998) Remote sensing and its applications for groundwater favourable area identification. Q J GARC 6:18e22 
Harinarayana P, Gopalakrishna GS, Balasubramanian A (2000) Remote sensing data for groundwater development and management in Keralapura watersheds of Cauvery basin, Karnataka, India. Indian Mineralogists Mineralogists 34:11e17

Krishna Kumar S, Chandrasekar N, Seralathan P, Godson Prince S, Magesh NS (2011) Hydrogeochemical study of shallow carbonate aquifers, Rameswaram Island, India. EnvironMonit Assess. doi:10.1007/s10661-011-2249-6

Leblanc M, Leduc C, Razack M, Lemoalle J, Dagorne D, Mofor L, (2003) Application of remote sensing and GIS for groundwater modeling of large semiarid areas: example of the Lake Chad Basin, Africa. In: Hydrology of Mediterranean and Semiarid Regions Conference, Montpieller, France. Red Books Series, 278. IAHS, Wallingford, p 186e192

Magesh NS, Chandrasekar N, Soundranayagam JP (2011a) Morphometric evaluation of Papanasam and Manimuthar watersheds, parts of Western Ghats, Tirunelveli district, Tamil Nadu India: a GIS approach. Environ Earth Sci 64:373e381

Magesh NS, Chandrasekar N, Vetha Roy D (2011b) Spatial analysis of trace element contamination in sediments of Tamiraparani estuary, southeast coast of India. Estuar Coast Shelf Sci 92:618e628

Muralidhar M, Raju KRK, Raju KSVP, Prasad JR (2000) Remote sensing applications for the evaluation of water resources in rainfed area, Warangal district, Andhra Pradesh. Indian Mineralogists 34:33e 40

Murthy KSR (2000) Groundwater potential in a semi-arid region of Andhra Pradeshda geographical information system approach. Int J Remote Sens 21:1867e1884

Prasad RK, Mondal NC, Banerjee P, Nandakumar MV, Singh VS (2008) Deciphering potential groundwater zone in hard rock through the application of GIS. Environ Geol 55:467e475

Rahman MdR, Saha SK (2008) Remote sensing, spatial multi criteria evaluation (SMCE) and analytical hierarchy process (AHP) in optimal cropping pattern planning for a flood prone area. J Spatial Sci 53(2):161-177

Saaty TL (1980) The Analytic hierarchy process. McGraw-Hill, New York

Sander P, Chesley M, Minor T (1996) Groundwater assessment using remote sensing and GIS in a rural groundwater project in Ghana: lessons learned. Hydrogeol J 4:78-93

Sarkar BC, Deota BS (2000) A geographic information system approach to ground water potential of Shamri micro-watershed in the Shimla Taluk, Himachal Pradesh. Unpublished Project Report submitted for NNRMS sponsored course on GIS; Technology and Application IIRS, NRSA, Dehradun, India, 24

Sener E, Davraz A, Ozcelik M (2005) An integration of GIS and remote sensing in groundwater investigations: a case study in Burdur, Turkey. Hydrogeology J 13:826e834

Shankar MNR, Mohan G (2006) Assessment of the groundwater potential and quality in Bhatsa and Kalu river basins of Thane district, western Deccan Volcanic Province of India. Environ Geol 49:990e998

Teeuw R (1995) Groundwater exploration using remote sensing and a low cost geographic information system. Hydrogeology J 3:21e 30

Thomas A, Sharma PK, Sharma MK, Sood A (1999) Hydrogeomorphological mapping in assessing groundwater by using remote sensing datada case study in Lehra Gage Block, Sangrur district, Punjab. J Indian Soc Remote Sens 27:31e42

Tiwari A, Rai B (1996) Hydromorphological mapping for groundwater prospecting using landsat e MSS imagesda case study of Part of Dhanbad District, Bihar. J Indian Soc Remote Sens 24:281e285

Tweed SO, Leblanc M, Webb JA, Lubczynski MW (2007) Remote sensing and GIS for mapping groundwater recharge and discharge areas in salinity prone catchments, southeastern Australia. Hydrogeology Journal 15:75e96 